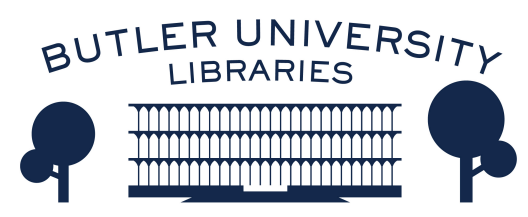

Journal of Hindu-Christian Studies

Volume 23

Article 16

January 2010

\title{
Book Review: "Jesus as Guru: The Images of Christ Among Hindus and Christians in India"
}

Swasti Bhattacharyya

Follow this and additional works at: https://digitalcommons.butler.edu/jhcs

Part of the Religion Commons

\section{Recommended Citation}

Bhattacharyya, Swasti (2010) "Book Review: "Jesus as Guru: The Images of Christ Among Hindus and Christians in India"," Journal of Hindu-Christian Studies: Vol. 23, Article 16.

Available at: https://doi.org/10.7825/2164-6279.1468

The Journal of Hindu-Christian Studies is a publication of the Society for Hindu-Christian Studies. The digital version is made available by Digital Commons @ Butler University. For questions about the Journal or the Society, please contact cbauman@butler.edu. For more information about Digital Commons @ Butler University, please contact digitalscholarship@butler.edu. 
presentation, wanting greater nuance and diversity of scholarly sources. However, Sharma does often note different scholarly opinions.

Finally, in Chapter Seven, Sharma asks the question at the forefront of many Hindus' minds: Must Christianity Proselytize? This last chapter on whether Christians are obligated to proselytize is in many ways the most important, as it addresses one of the fundamental concerns Hindus have regarding Christianity. Sharma rightly shows that Christianity need not proselytize (although it has been and remains a strong impulse). However, I would have liked a longer and more sympathetic treatment of the many Christian groups that have labored to put their violent past behind them and move positively toward a more inclusive approach. There are many positive Christian resources for dialogue without proselytization, and it is just as valuable for Hindus to be aware of them as it is for Christians.

As a book intended for a popular audience, it is largely successful. Sharma distills a remarkable amount of information into a short 100 -pages. This is an impressive achievement for such a short book. Sharma's explanations and examples serve to render Christianity understandable to a Hindu reader. He argues convincingly that Hindus ought to learn about Christianity and understand it on its own terms. Sharma's many long quotes make the book less readable, though the text is on the whole quite accessible.

Sharma's book is valuable for a wide range of Hindus interested in learning the basics of Christianity. It is sufficiently nuanced to be a fairly accurate presentation of the major points of Christianity and addresses the key issues of concern for Hindu audiences. Sharma is to be thanked for this important contribution to Hindu and Christian understanding.

Tracy Sayuki Tiemeier Loyola Marymount University

\section{Jesus as Guru: The Images of Christ Among Hindus and Christians in India. Jan Peter Schouten. Translated by Henry and Lucy Jansen. Amsterdam: Rodopi, 2008, 314pp.}

SCHOUTEN sets out to "discuss Hindus and Christians from the last two centuries who have contributed to the development of Christology in India." (4) His discussion is presented in 11 chapters and five "intermezzos," short essays that focus on particular artists' images of Jesus. Each chapter begins with a brief introduction to an individual or group, highlighting their background and relationship to religion. This is followed by a presentation of the person or group's understanding of, or teachings, regarding Jesus. Not surprisingly, Schouten's book basically confirms" what R. S. Sugirtharajah once wrote: "Whereas EuroAmerican Christological reflections ... prefer to discover Jesus in the pages of the written text and place him in a social, political and religious environment, Asian understandings of Jesus. . . take him out of his milieu and place him with the peoples of Asia and with other venerated sages like Buddha, Krishna, and Confucius. They try to take Jesus out of the study into the dusty streets of Asia and let him mingle with other seers and savior figures." (Sugirtharajah, R. S. Asian Faces of Jesus. New York: Orbis Books, 1993; x)

In the introduction Schouten indicates that the "East and West have something to tell each other" (4), and in Jesus as Guru the author presents an interesting, richly diverse array of images of Jesus originating from India. Schouten begins chapter 2 with an exploration of Ram Mohan Roy's images of Jesus. Roy, a Hindu and one of the first to publically debate the meaning of Jesus in India, sees Jesus as a teacher, a divine guru teaching peace and happiness. Roy claims Jesus as a "fellow Asian" and questions the validity of Europeans seeing Jesus as their own. Nehemiah Goreh, India's "Hindu Paul," according to Schouten, is the 
focus of chapter 3. Goreh began as a scholarly opponent to Christianity, only to convert and to become one of the first native Indian Christian theologians. As a theologian, Goreh emphasized Jesus' role as the second person of the Trinity. Through her work with high caste women, Pandita Ramabai, the subject of chapter 4, was inspired by the practical, social work aspects of how Christian church groups showed mercy to all people in trouble, even "fallen" women. As she pursued her ministry to women, she focused on the teaching that Jesus was the savior of all.

While Ramabai was attracted to Christianity and developed her understanding of Jesus in a "this worldly" context, in chapter 5 Schouten traces the development of an "other worldly" Christology in the Ramakrishna Mission. He begins with the ideas of Ramakrishna, where Jesus is seen as a yoga master, an accomplished ascetic. He then moves to Vivekananda's application of Advaita Vedanta philosophy to his image of Jesus as a world renouncer. Finally Schouten focuses on two monks who were missionaries to the USA: Prabhavananda and Akhilananda. They too focused on the philosophical aspect of Jesus as one who realized divinity through his own efforts. Though the Indians in the previous chapters are depicting Jesus through their lenses (be it in a Hindu or Christian context), in chapter 6 the author claims that V. Chkkarai is the first to "Indianize" Jesus, identifying Jesus as the Avatar. While Rama and Krishna are avatars, they are temporary. However Jesus, according to Chakkarai, is permanent.

M. K. Gandhi is the focus of chapter 7. Here Schouten highlights the similarities between the life of Jesus and that of M.K. Gandhi. Jesus is the "prince of passive resisters," the one who completely identifies and works for the least in society (sarvodaya). Jesus' ethical teachings, particularly in his Sermon on the Mount, are at the core of how Gandhi understands Jesus. While the author acknowledges that Gandhi never converted to Christianity, he seems to want to see Gandhi as being an exemplary Christian.

Chapter 8 begins with a brief introduction to various Protestant and Catholic groups and individuals that established different Christian ashrams. While some work to create a distinctly Christian identity, others labor to encase Christian theology/ideology in Indian/Hindu traditions. While some follow the idea of social service, others set up "world-renouncing" hermitages. From this diverse group of Christian ashrams come an equally abundant variety of images of Jesus: Jesus as Sadhu, Jivanmukta, the only one reality (Advita Vedanta), the Eternal Christ, cosmic figure, and Jesus as Christ in Saccidananda.

"The Great 3: Panikkar, Thomas, Samartha" are the focus of chapter 9. These three individuals not only represent different branches of Christianity (Roman Catholic, Eastern Orthodox, Protestant), and three different ways of living in the world (academic, activist for social justice, minister of a church), but also three different Christological images. Not surprisingly, the images of Jesus presented correlate with the focus the person had in his life. The academic saw Jesus as a mystical philosopher. The activist highlighted Jesus' social justice work for all, and finally the minister focused on a Christology involving being part of the body of the church.

Chapter 10 focuses on the development of Christianity in regards to the dalit population in India. In the 1980s, Indian theologians looked to the liberation theologians of the USA and Latin America as they developed their liberation dalit theology. According to Schouten, "For the Indian Christian dalits, to know Jesus Christ is to realize that the God of Jesus Christ will save them from inhumanity, social oppression, economic exploitation and cultural subjugation." (243).

In the 5 Intermezzos Schouten talks about how five different Indian artists (Frank Wesley, Nandalal Bose, Alfred Thomas, Jyoti Sahi, and Susheila Williams) take the images of Jesus and depict him in "traditional" Indian or Hindu settings. While one consciously made use of Hindu stylistic devices to portray themes of the Christian faith, others portray Jesus as mischievous child with blue skin, or clothed in a lungi, or looking like the Buddha calling upon the earth as a witness, or hanging from a tree in an adivasi village. Schouten's final chapter presents a summation of his findings. 
There is much to be learned from and appreciated in Schouten's Jesus as Guru. However, I was frustrated by phrases such as "Whoever explores the religion and culture of India comes fact to face with a different world," (1) or "...Since then, it is no longer possible to imagine Indian society and culture without Christ." (4) Following an informative intermezzo on Frank Wesley's depiction of Jesus as a blue hued child like Krishna, I wonder why he felt the need to say, "The representation of Jesus is certainly not very accurate historically." (127) These examples, and others, seem to reflect a presumed position of privilege for Caucasian, Western/European, Christian contexts.

While dialogue between "East" and "West" sets the context for the book in the introduction, in the Postscript Schouten acknowledges, “...in the past quarter of a century the voice of Hindus in the dialogue has grown silent." (260) Perhaps future work can assess why this might be so and work to build a new conversation.

Swasti Bhattacharyya

Buena Vista University

\section{Yoga Body: The Origins of Modern Posture Practice by Mark Singleton. Oxford: Oxford University Press, 2010, pp. viii +262 and The Yoga Sutras of Patanjali by Edwin F. Bryant. New York: North Point Press, 2009, pp. 1xvii + 598.}

BEFORE tackling Mark Singleton's Yoga Body, one should first read Elizabeth De Michelis' A History of Modern Yoga (Continuum, 2004) where she sets the context for the various forms of modern postural or asana yoga in Vivekananda's lectures on Raja Yoga in 1896 delivered just after the Chicago Parliament of Religions. While Vivekananda purports to be presenting Patanjali's, Yoga, he is actually basing his version of Yoga on Keshubchandra Sen along with Theosophy, William James, Krishnamurti and others, and ends up emphasizing mental practice over the physical. Having identified the intellectual root of Modern Yoga as Vivekananda's Raja Yoga, De Michelis shows how in the twentieth century, two developments arise out of Vivekananda, namely Modern Postural Yoga and Modern Meditational Yoga. Mark Singleton studied these historical developments of Yoga together with De Michelis (also his $\mathrm{PhD}$. supervisor) when the two of them plus Suzanne Newcombe organized the Modern Yoga Graduate Workshop at the Divinity Faculty, University of Cambridge in 2006. Singleton's attention came to be focused on a gap in the development of the Postural Yoga side arising from Vivekananda. While Vivekananda's 1890s Raja Yoga emphasized mental practice and tended to shun the asana or posture side as being unsuitable, Singleton notes that by the 1920 s posture oriented forms of yoga began to re-emerge and dominate. This then is the focus of Singleton's Body Yoga, namely to offer a good explanation of why asana or postural yoga was initially excluded, and to describe the various ways in which it was eventually reclaimed. Body Yoga, says Singleton, "aims to indentify the factors that initially contributed to the shape that transnational yoga has taken today, and constitutes in some ways a 'prehistory' of the international asana revolution that got into full swing with B. K. S. Iyengar and others from the 1950s onward." Singleton supports this contention by noting that in doing the literature review for Yoga Body, the English language yoga manuals from the late 1800 s to about 1935 largely follow Vivekananda's mental yoga in their approach. In surveying the holdings of Cambridge University Library and the British Library in London, as well as Stanford University's Green Library and the University of California, Berkeley library, Singleton found that the asana or practice oriented Anglophone yoga manual begins to emerge as a genre only during the 1920s. It is these manuals that 